\title{
ОСОБЛИВОСТІ ІНСТИТУЦІОНАЛІЗАЦІЇ СПІВПРАЦІ ОРГАНІВ ПУБЛІЧНОГО УПРАВЛІННЯ $З$ ОРГАНІЗАЦІЯМИ ГРОМАДЯНСЬКОГО СУСПІЛЬСТВА
}

\begin{abstract}
У статті аналізується поняття «інституиііоналізація» та надано оиінку стану розвитку взаємодії організацій громадянського суспільства з органами публічного управління. Аналіз актуального стану громадянського суспільства в Украӥні свідчить про існуючі проблеми у сфері ефективної співпраці з органами влади, які гальмують подальше зростання громадської активності та перешкоджають ефективному використанню громадських організацій для захисту прав та реалізаиії законних інтересів громадян. Тому в Україні існує потреба у виробленні механізмів ефективної взаємодії держави та громадянського суспільства, оскільки органи публічного управління, співпрацюючи з інститутами громадянського суспільства, в такий спосіб можуть підвищувати результативність своєї діяльності та рівень довіри громадян до влади.

Вивчено різні підходи науковців до визначення проблем ефективної співпраці органів публічного управління з громадянським суспільством, а також визначено основні принципи і форми такої взаємодіі. Взаємодія органів публічного управління з ОГС має здійснюватись на засадах гласності, відкритості та прозорості. У результаті діалогу між суб'єктами відбувається $i$ взаємовплив, $i$ конструктивна співпрачя. Завдяки цьому процесу між владою та громадянами стає можливим контроль громадськості за діяльністю органів публічного управління, тобто в процесі взаємодії влада має намагатися досягнути консенсусу у відносинах $i$ застосовувати для изього різноманітні механізми та форми з метою задоволення потреб громадян, народу як суверена влади.

Надано оцінку існуючим механізмам взаємодї органів публічної влади з недержавними організаціями. Побудова ефективних партнерських відносин між громадянами $і$ органами публічної влади передбачає постійний аналіз проблем, оиінку проблем та інтересів, розвитку взаємодї, співробітництва і взаємної відповідальності; налагодження двостороннього зв'язку, спрямованого на спільний пошук шляхів вирішення найактуальніших проблем; забезпечення довіри з боку громадян до влади. Запропоновано форми взаємодії організацій громадянського суспільства з органами влади.
\end{abstract}

Ключові слова: активізачія, взаємодія, громадська думка, громадянське суспільство, делегування, інститут, інституціоналізація, комунікація, механізми взаємодії.

C.B. СОРОКА

Черноморский национальный университет им. Петра Могилы ORCID: 0000-0003-2022-0388

С.В. ЛИЗАКОВСКАЯ

Военно-морская академия им. Героев Вестерплатте, г. Гдыня, Республика Польша ORCID: 0000-0002-1524-2673

\section{ОСОБЕННОСТИ ИНСТИТУЦИОНАЛИЗАЦИИ СОТРУДНИЧЕСТВА ОРГАНОВ ПУБЛИЧНОГО УПРАВЛЕНИЯ С ОРГАНИЗАЦИЯМИ ГРАЖДАНСКОГО ОБЩЕСТВА}

В статье аналиируется понятие «институцฺионализация» и дана оценка состояния развития взаимодействия организаичй гражданского общзества с органами публичного управления. Анализ актуального состояния гражданского общества в Украине свидетельствует о существующих проблемах в сфере эффективного сотрудничества с органами власти, тормозящие дальнейший рост общественной активности и препятствующие эффективному использованию общественньх организаций по защчите прав и реализации законных интересов граждан. Поэтому в Украине существует потребность в выработке механизмов эффективного взаимодействия государства и гражданского общества, поскольку органь публичного управления, сотрудничая с институтами гражданского общества, таким образом могут повышать результативность своей деятельности и улучшать уровень доверия граждан к власти. 
Изучены различные подходы ученых к определению проблем эффективного сотрудничества органов публичного управления с гражданским обществом, а также определень основные принципь и формы такого взаимодействия. Взаимодействие органов публичного управления с общественными организациями должно осуществляться на принципах гласности, открытости и прозрачности. В результате диалога между субъектами происходит $u$ взаимовлияние, $u$ конструктивное сотрудничество. Благодаря этому процессу между властью и гражданами становится возможным контроль общественности за деятельностью органов публичного управления, то есть в процессе взаимодействия власти достигают консенсуса в отношениях и применяют для этого различные механизмы и формы с целью удовлетворения потребностей граждан, народа как суверена власти.

Дана оиенка существуюшим механизмам взаимодействия органов публичной власти с негосударственныли организациями. Построение эффективных партнерских отнотений между гражданами и органами публичной власти предполагает постоянный анализ проблем, оиенку проблем и интересов, развития взаимодействия, сотрудничества и взаимной ответственности; налаживание двусторонней связи, направленного на совместный поиск путей решения актуальных проблем; обеспечения доверия со стороны граждан к власти. Предложены формы взаимодействия организаций гражданского общества с органами власти.

Ключевые слова: активизащия, взаимодействие, общественное мнение, гражданское общество, делегирование, институт, институичинализациия, коммуникация, механизмы взаимодействия.

S.V. SOROKA

Petro Mohyla Black Sea National University ORCID: 0000-0003-2022-0388

S. V. LIZAKOWSKA

Polish Naval Academy, Poland

ORCID: 0000-0002-1524-2673

\section{INSTITUTIONALIZATION OF COOPERATION BETWEEN CIVIL SOCIETY ORGANIZATIONS AND PUBLIC AUTHORITIES}

The article analyzes the concept of "institutionalization" and provides an assessment of the state of development of interaction between civil society organizations and public administration. The analysis of the current state of civil society in Ukraine shows the existing problems in the field of effective cooperation with the authorities, which hinder the further growth of public activity and prevent the effective use of public organizations to protect the rights and legitimate interests of citizens. Therefore, in Ukraine there is a need to develop mechanisms for effective interaction between the state and civil society, as public administration bodies, cooperating with civil society institutions, can thus increase the effectiveness of their activities and the level of citizens' trust in government.

Different approaches of scientists to determining the problems of effective cooperation of public administration bodies with civil society have been studied, as well as the basic principles and forms of such interaction have been identified. The interaction of public administration bodies with NGOs should be carried out on the basis of transparency, openness and transparency. As a result of dialogue between the subjects, there is both interaction and constructive cooperation. This process between the government and citizens makes it possible for the public to control the activities of public administration, ie in the process of interaction the government should try to reach a consensus in relations and use various mechanisms and forms to meet the needs of citizens as a sovereign.

The assessment of the existing mechanisms of interaction of public authorities with non-governmental organizations is given. Building effective partnerships between citizens and public authorities involves constant analysis of problems, assessment of problems and interests, development of interaction, cooperation and mutual responsibility; establishing two-way communication aimed at jointly finding ways to solve the most pressing problems; ensuring public confidence in the government. Forms of interaction of civil society organizations with the authorities are proposed.

Key words: activation, interaction, public opinion, civil society, delegation, institute, institutionalization, communication, interaction mechanisms.

\section{Постановка проблеми}

Необхідність проведення дослідження на визначену тематику обумовлена тим, що в сучасних соціально-політичних умовах формування демократичної держави неможливе без розвиненого громадянського суспільства, яке стає дієвим партнером в процесі державотворення за умови конструктивного та соціально відповідального діалогу з органами публічного управління. 
В умовах широкої демократії держава поступається частиною своїх повноважень у державній та управлінській сферах соціальної життєдіяльності структурам, що самоорганізуються та самоуправляються. Досвід демократичних держав показує, що саме громадська участь та активність дозволяє досягти більшої ефективності в багатьох сферах суспільного життя - від реалізації соціальної політики до сфери публічного управління. Взаємодія держави 3 інститутами громадянським суспільством необхідна для розвитку України як демократичної i соціальної держави, так як демократичний розвиток та економічне зростання, прогрес важко реалізовувати без активної участі активних громадян.

В сучасних соціально-економічних умовах без розвиненого громадянського суспільства неможливо вдосконалювати публічне управління, яке вимагає реальної участі громадян в процесі обговорення та прийнятті управлінських рішень, реалізації публічних політик. Стратегічний підхід розбудови демократичного суспільства і успішної країни передбачає налагодження системного діалогу органів публічного управління з громадськістю через конструктивну інституалізацію. Важливою умовою розвитку країни та благоустрою її громадян $є$ інституціоналізація співпраці вищезазначених органів та громадянського суспільства, яка сприяє взаємообумовленому розвитку даних суб'єктів.

Умовою розбудови демократичного суспільства $\epsilon$ залучення інститутів громадянського суспільства до участі в публічному управлінні, організація та забезпечення їх вільного доступу до інформації про діяльність влади, створення умов для відкритості та прозорості в діяльності органів влади, підвищення якості реалізації публічних політик шляхом врахування потреб громадськості. Саме тому розв'язання проблеми співпраці інститутів громадянського суспільства 3 органами публічного управління сьогодні набуває особливого значення.

Зокрема, в Україні існує потреба у виробленні механізмів ефективної взаємодії держави та громадянського суспільства, оскільки органи публічного управління, співпрацюючи 3 інститутами громадянського суспільства, в такий спосіб можуть підвищувати результативність своєї діяльності та рівень довіри громадян до влади.

\section{Аналіз останніх досліджень і публікацій}

Вивчення та аналіз взаємодії органів публічного управління та інститутів громадянського суспільства відображені в наукових працях дослідників: М. Бебика, І. Бекешкіної, В. Бульби, І. Колосовської, В. Купрія, М. Логунової, В. Ребкало, Ю. Сурміна, Т. Тарасенка, С. Телешуна, В. Тертички, І. Хохрякової, В. Яблонського та ін.

\section{Формулювання мети дослідження}

Метою статті $\epsilon$ аналіз співпраці органів публічного управління з організаціями громадянського суспільства через призму інституалізації, виявлення ролі та місця недержавних організацій у процесі розвитку демократичної держави.

У процесі дослідження були сформульовані наступні завдання:

- аналіз поняття і змісту терміна «інституціоналізація»;

- розглянути основні принципи і форми співпраці організацій громадянського суспільства 3 органами влади;

- запропонувати ефективну модель інституціоналізації взаємодії організацій громадянського суспільства $з$ органами публічного управління.

\section{Виклад основного матеріалу дослідження}

В основі терміна «інституціоналізм» лежить поняття «інститут», яке розглядається та аналізується як первинний елемент рушійної сили суспільства в економічній сфері та поза ії межами. Класично, до інститутів відносять державу, сім'ю, підприємництво, монополії, профспілки, общини, організації - все, що демонструє та показує традиції, звичаї, етичні норми поведінки, правові рішення, психологічні елементи поведінки та соціально-економічні відносини.

Класичним та широковідомим є визначення Нобелівського лауреата Д. Норта: «Інститути - це «правила гри» в суспільстві, створені людиною, обмежувальні рамки, які організовують взаємовідносини між людьми» [7, с. 17].

Інституціоналізація в публічному управлінні - це процес визначення і закріплення соціальних норм, стандартів, правил та впорядкування і формалізації сталих відносин між складовими елементами публічного управління, зведення їх у систему, орієнтовану на задоволення найважливіших суспільних потреб суспільства у вигляді законів, соціальних норм або усталеного порядку, що підвищує його результативність та ефективність. Тобто інституціоналізація - це процес створення постійних або тимчасових форм взаємодії і співпраці сторін, які запобігають виникненню конфлікт, допомагають вирішувати суперечливі питання і конструктивно співпрацювати.

Варто зазначити, що наявність інститутів в державі $є$ ознакою та елементами стабільності суспільства. Якщо в суспільстві не формуються інституційні засади впливу на публічне управління і громадянське суспільство не залучається до державного будівництва, то політична система суспільства 
деформується в бік ії тоталітаризації і державне управління втрачає публічність як основний елемент демократичної управлінської моделі.

Концепція взаємодії органів публічного управління з громадянським суспільством спрямована на посилення процесу демократизації влади, розвиток і зміцнення недержавних організацій, посилення їхнього зв'язку та $\epsilon$ виразом налаштування органів влади до співробітництва 3 інститутами громадянського суспільства з метою подальшого вдосконалення партнерських відносин.

Під поняттям «громадянське суспільство» розуміють сукупність відносин, які виникають на засадах добровільності та самоорганізації між громадянами та створеними ними організаціями для задоволення інтересів, а також такі відносини, що розвиваються поза родинними та комерційними $[9, \mathrm{c}$. 9]. У громадянському суспільстві діють формальні організації - організації громадянського суспільства (далі - ОГС), основними ознаками яких є:

- громадський характер - незалежність від органів публічного управління;

- некомерційний характер - відсутність мети заробку та розподілу прибутку від діяльності між засновниками та учасниками, що унеможливлює отримання доходу для діяльності таких організацій;

- добровільний характер - створення за ініціативою громадян та визначення цілей і способів їх діяльності на розсуд громадян.

Метою формування та створенні організацій громадянського суспільства $є$ спільна діяльність, яка спрямована на соціальне лобіювання (представлення інтересів різних соціальних груп) і захист колективного інтересу відповідно до чинного законодавства. Україні $\epsilon$ :

У працях вітчизняних науковців зазначається, що функціями громадянського суспільства в

- забезпечення участі організацій громадянського суспільства у створенні та реалізації публічної політики шляхом забезпечення конструктивного та ефективного представництва інтересів громадян в органах публічного управління, проведення консультацій із громадськістю шляхом організації публічного обговорення актуальних та нагальних питань у державі;

- запровадження громадського контролю за діяльністю органів публічного управління, посилення впливу організацій громадянського суспільства на прийняття управлінських рішень та контроль за їх реалізацією.

Щодо головних ознак сучасного громадянського суспільства, науковці відзначають такі його риси:

- висока політична культура членів суспільства у поєднанні з високим розвитком політичних, економічних, правових та культурних відносин;

- забезпеченість повноти прав і свобод громадянина;

- широкий розвиток інститутів органів місцевого самоврядування;

- розвиток ринкової економіки на засадах приватної та колективної власності [11].

Важливою рисою громадянського суспільства $є$ певний рівень сформованості масової свідомості, готовність громадян до активної участі в реалізації публічної політики [11].

Під взаємодією органів публічної влади з громадянами розуміють різноманітні форми співпраці, які відображають пошук спільного поля діяльності і передбачають досягнення консенсусу обома сторонами. Держава у формуванні та зміцненні інститутів громадянського суспільства відіграє найважливішу роль, використовуючи законодавчі механізми, економічні важелі і готовність до співробітництва [2, с. 305].

Указом Президента України «Про сприяння розвитку громадянського суспільства в Україні» затверджено «Національну стратегію сприяння розвитку громадянського суспільства в Україні на 20162020 роки» [6].

Метою Стратегії є створення сприятливих умов для розвитку громадянського суспільства, налагодження ефективної взаємодії громадськості з органами державної влади, органами місцевого самоврядування на засадах партнерства, забезпечення додаткових можливостей для реалізації та захисту прав і свобод людини і громадянина, задоволення суспільних інтересів з використанням різноманітних форм демократії участі, громадської ініціативи та самоорганізації. Реалізацію Стратегії передбачається здійснювати за такими стратегічними напрямами:

- створення сприятливих умов для формування та інституційного розвитку організацій громадянського суспільства;

- забезпечення ефективних процедур участі громадськості під час формування та реалізації державної, регіональної політики, вирішення питань місцевого значення;

- стимулювання участі організацій громадянського суспільства в соціально-економічному розвитку України;

- створення сприятливих умов для галузевої співпраці [6].

Аналіз актуального стану громадянського суспільства в Україні свідчить про існуючі проблеми у сфері ефективної співпраці з органами влади, які гальмують подальше зростання громадської активності 
та перешкоджають ефективному використанню громадських організацій для захисту прав та реалізації законних інтересів громадян. Науковці Є. Бородін, Т. Тарасенко О. Турій, І. Хохрякова, окреслюючи існуючі проблеми, стверджують, що сьогодні:

- зберігаються тенденції до непрозорості, закритості та забюрократизованості в діяльності органів виконавчої влади замість налагодження ефективного діалогу з суспільством;

- недосконалість чинного законодавства створює штучні бар'єри для утворення та діяльності інститутів громадянського суспільства;

- механізми участі громадськості у формуванні та здійсненні державної політики належним чином не реалізовуються;

- податкове навантаження не стимулює діяльність і розвиток інститутів громадянського суспільства та їх підтримку вітчизняними благодійними організаціями;

- недостатність фінансової бази діяльності суб'єктів громадянського суспільства - більшість інститутів громадянського суспільства не має доступу до державної фінансової підтримки та вітчизняної благодійної підтримки;

- потенціал інститутів громадянського суспільства щодо надання соціальних послуг населенню не використовується;

- недостатня участь громадських організацій у процесі підготовки, публічного обговорення та прийняття управлінських рішень;

- відсутність системного інформування населення про існуючі організації громадянського суспільства та їх діяльність;

- суттєві розбіжності між формальною інституціоналізацією та реальною активністю громадянського суспільства, а саме реальними можливостями контролювати і впливати на процес вироблення і прийняття політичних рішень, визначати складові соціальної політики, виступати сферою проведення діалогу між зацікавленими сторонами [11; 14].

Отже, як зазначено в аналітичній розробці Національного інституту стратегічних досліджень, сьогодні в Україні переважають форми опосередкованої участі громадськості порівняно 3 формами безпосередньої участі громадськості та взаємодії органів влади з громадянами та їх об'єднаннями на місцевому рівні. Механізм громадських слухань, загальних зборів за участю жителів територіальної громади за місцем проживання, впровадження іншого досвіду реалізуються недостатньо [9].

Українські дослідники Т. Андріученко, І. Бекешкіна і В. Яблонський зазначають, що у процесі розвитку вітчизняного громадянського суспільства виявилися й кризові тенденції щодо громадської участі: лише 6,6\% українських громадян залучені до активної громадської діяльності. Водночас розчарування повільними темпами реформ примушує громадян шукати прості рішення, які почасти проявляються в радикалізації протестів, створенні під окремого політика чи певну політичну силу формувань на тлі дефіциту демократичної політичної культури. Динаміка інституалізації громадянського суспільства упродовж 2014-2018 pр. засвідчує тенденцію до повільного зростання в 2015 р., і в наступні роки також, кількості зареєстрованих громадських організацій в Україні. Так, станом на 1 грудня 2015 р. - 69 686, на 1 грудня 2016 р. - 75 478, на 1 квітня 2017 р. - 77 252, а станом на 1 квітня 2018 р. налічувалося 81598 громадських організацій [3].

В аналітичній записці НІСД досліджується взаємодія ОГС із органами публічного управління, вплив організацій на формування та реалізацію державної політики. Зазначається, що ця взаємодія ускладнюється через:

- використання ОГС у політичному процесі (штучна активізація у виборчий період, відстоювання інтересів, прав, запитів не громадян, а партійно-політичних сил, приватних i корпоративних інтересів фінансово-промислових груп, посадових осіб державних органів та органів місцевого самоврядування);

- створення імітаційних громадських рухів та ініціатив, які з використанням ОГС маскуються під стихійні реакції груп громадян, невдоволених діями чи рішеннями органів державної влади;

- брак прийнятних фінансових, кадрових, організаційних можливостей ОГС, фіктивність значної кількості ОГС, невідповідність змісту діяльності заявленим статутним завданням;

- систематичне ігнорування з боку органів державної влади як громадської думки в цілому, так $\mathrm{i}$ позицій ОГС, висловлених у процесі консультацій, у проведених експертизах, моніторингах, слуханнях при прийнятті остаточних рішень;

- дискредитацію потенційно ефективних процедур консультацій з громадськістю, громадської експертизи, слухань;

- надання формалізованих відповідей на інформаційні запити до органів державної влади, безпідставних відмов у наданні інформації, а також неналежне і неповне ії оприлюднення;

- наповнення веб-сайтів органів державної влади переважно інформацією про фіксацію створення громадських рад, проведення слухань, експертиз, а не їхнього внеску в зміст прийнятих рішень чи їх коригування; 
- несиметричність практики соціального діалогу, участі його сторін (у переговорних процесах профспілкова сторона поступається важелям впливу органів державної влади та сторони роботодавців) [14].

Крім того, потенціал громадянського суспільства реалізується через механізми участі громадян у процесі розробки та прийняття політичних рішень саме тому, що від якості державно-політичних рішень, які приймаються, в подальшому залежить і ефективність управління державою, а одним з важливих політичних завдань в сучасній державі є забезпечення рівноваги в суспільстві.

Законодавчою основою регулювання діяльності інститутів громадянського суспільства в Україні $\epsilon$ наявність прийнятих документів та актів:

- Закони України: «Про асоціації органів місцевого самоврядування», «Про громадські об'єднання», «Про засади державної регуляторної політики у сфері господарської діяльності», «Про професійні спілки, їх права та гарантії діяльності», «Про соціальний діалог в Україні»;

- Указ Президента України «Про Стратегію державної політики сприяння розвитку громадянського суспільства в Україні та першочергові заходи щодо ії реалізації»;

- Постанови Кабінету Міністрів України: «Порядок сприяння проведенню громадської експертизи діяльності органів виконавчої влади», «Про забезпечення участі громадськості у формуванні та реалізації державної політики», «Про затвердження Порядку залучення громадян до формування та реалізації державної політики».

Взаємодія органів публічного управління з ОГС має здійснюватись на засадах гласності, відкритості та прозорості. У результаті діалогу між суб'єктами відбувається і взаємовплив, i конструктивна співпраця. Завдяки цьому процесу між владою та громадянами стає можливим контроль громадськості за діяльністю органів публічного управління, тобто в процесі взаємодії влада має намагатися досягнути консенсусу у відносинах і застосовувати для цього різноманітні механізми та форми з метою задоволення потреб громадян, народу як суверена влади.

Залучаючи громадськість до процесу прийняття рішень, спільної взаємодії, влада виступає як суб'єкт: вона впливає на громадськість з метою активізації іiі діяльності, створює необхідні для цього умови. У результаті цього громадськість, яка відігравала роль об'єкта діяльності влади, перетворюється на суб'єкт: вона починає впливати на владу, контролювати ії та диктувати свої умови [2, с. 301-302].

У Проекті Концепції взаємодії держави з громадянським суспільством, запропонованому КМУ, для підвищення ефективності взаємодії органів влади з ОГС, розвитку партнерських відносин пропонується активно використовувати як уже закріплені в чинному законодавстві України форми взаємодії, що перевірені вітчизняним і міжнародним досвідом, так і нові форми, а саме:

- підтримка діяльності різних за спрямуванням громадських організацій (дитячих, молодіжних, студентських, жіночих, екологічних організацій тощо, об'єднань ветеранів, пенсіонерів, інвалідів, працівників науки, культури, охорони здоров'я, етнокультурних та інших формувань);

- залучення ОГС до розробки, виконання й громадської експертизи проектів законодавчих актів і програм соціального розвитку;

- розміщення та укладання договорів державного замовлення;

- створення асоційованих структур (державно-громадські, громадсько-державні фонди, асоціації, партнерства), які мають визначене коло завдань і створюються за принципом цільового підходу для їх досягнення та вирішення;

- створення різних спільних консультативно-дорадчих органів, експертних рад, комісій, груп тощо;

- проведення цілеспрямованої політики щодо підготовки кадрів і взаємного навчання державних службовців та представників ОГС навичок і практики роботи в партнерстві один з одним [5].

Роль органів публічного управління полягає в тому, щоб сприяти розвитку громадянського суспільства та заохочувати громадян до субсидіарності. На думку О. Скакуна, роль цивілізованої держави у розвитку громадянського суспільства полягає в тому, що вона:

- слугує формою, що організовує громадянське суспільство і створює умови для його розвитку;

- є відносно самостійною щодо громадянського суспільства і здійснює солідарні публічні інтереси всіх членів суспільства;

- встановлює «правила гри», яких повинні дотримуватися громадяни та їх об'єднання, створює сприятливі умови для їх існування і розвитку;

- не втручається в приватну сферу сім’і, побуту, культури: таке втручання можливе лише 3 метою забезпечення особистої або громадської безпеки;

- не втручається в приватні (громадянські) правовідносини: у разі вступу в такі правовідносини втрачає можливість виявляти публічну владу;

- надає необхідний захист громадянському суспільству, яке функціонує в межах іiі території, у тому, що належить до соціальної безпеки його суб’єктів; 
- виступає знаряддям соціального компромісу громадянського суспільства, пом'якшує соціальні суперечності між різними соціальними групами;

- юридично забезпечує можливості громадянина бути власником, створювати громадські об’єднання, комерційні корпорації, брати активну участь у політичному житті суспільства;

- має межі регулювання відносин у суспільстві, що визначаються конституцією держави, міжнародними стандартами прав людини [10, с. 21].

Тобто, органи публічно ї влади позиціонують себе як партнер у взаємовідносинах 3 громадянами, який шукає конструктивні рішення з метою підвищення рівня якості життя, заспокоєння найважливіших потреб громадян в країні.

Науковець I. Колосовська вказує, що основними напрямами і формами взаємодії інститутів влади та громадянського суспільства $є$ :

- забезпечення відповідних правових умов для функціонування та розвитку інститутів громадянського суспільства;

- активізація дієвої співпраці органів публічної влади з громадськістю в процесі вироблення і реалізації політики на загальнодержавному, регіональному та місцевому рівнях;

- підтримка ініціатив та залучення потенціалу громадських організацій у сфері надання публічних послуг та вирішення соціальних проблем громадян;

- підвищення рівня інституційної спроможності суб'єктів громадянського суспільства щодо використання механізмів участі громадськості у формуванні й реалізації публічної політики;

- використання інтерактивних форм зв'язків із громадськістю; підвищення рівня інформованості суспільства шляхом провадження ефективної інформаційно-просвітницької роботи щодо діяльності інститутів громадянського суспільства [4, с. 166].

Можна зауважити, що наявний потенціал громадянського суспільства може виступати додатковим ресурсом для вирішення наявних проблем в країні.

Згідно з роз'ясненням Міністерства юстиції України щодо взаємодії держави та інститутів громадянського суспільства, сьогодні ця взаємодія відбувається у таких правових формах:

1. Участь інститутів громадянського суспільства у нормотворчій діяльності держави, яка забезпечується участю у розробленні та обговоренні проектів нормативно-правових актів.

2. Участь інститутів громадянського суспільства у правозастосовній діяльності держави, яка забезпечується шляхом:

- передання повноважень державних органів повністю;

- передання повноважень державних органів частково;

- громадського контролю.

3. Участь інститутів громадянського суспільства у правоохоронній діяльності держави, яка забезпечується шляхом:

- реалізації права складати протоколи про адміністративні правопорушення;

- участі інститутів громадянського суспільства у діяльності органів внутрішніх справ щодо забезпечення охорони громадського порядку;

- реалізації права вживати спільно 3 працівниками поліції заходів щодо припинення адміністративних правопорушень і злочинів [1, с. 22].

Отже, завдяки сприянню розвитку громадянського суспільства держава:

- частково звільняє себе від функції надання соціальних послуг із збереженням високих соціальних стандартів для населення;

- покращує якість публічно-правових рішень через більш повне врахування потреб населення, альтернатив та можливих наслідків рішень; рішень;

- підвищує рівень довіри до органів публічної влади та рівень легітимності публічно-правових

- забезпечує готовність населення до належного виконання публічно-правових рішень [2, с. 10].

Таким чином, рівновага між організаціями громадянським суспільством і органами публічного управління $є$ вагомим чинником стабільного демократичного розвитку, що має базуватися на усвідомленні владою та громадянами відповідальності за прийняті рішення на різних рівнях (від локального до національного) та щоденного виконання кожною стороною своїх завдань. Органам публічного управління в процесі розбудови демократичних принципів у країні доцільно зосередитись на наступних кроках: та ініціативи;

- надавати суспільству вчасну, точну та повну інформацію про законодавство, служби, послуги

- пояснювати свою політику та рішення, інформувати суспільство про пріоритети для країни;

- забезпечувати відкритість, доступність та підзвітність громаді, якій вони покликані служити;

- консультуватися 3 громадськістю, враховувати інтереси та проблеми людей у процесі встановлення пріоритетів, планування програм та послуг, розвитку ініціатив; 
- постійно підтримувати діалог з громадськістю, що є похідним від права громадян звертатися до уряду і бути ним почутим, з метою дослідження, оцінки та врахування потреб громадян і їх очікувань для отримання найповнішої відповіді на них [2].

Побудова ефективних партнерських відносин між громадянами і органами публічної влади передбачає постійний аналіз проблем, оцінку проблем та інтересів, розвитку взаємодії, співробітництва і взаємної відповідальності; налагодження двостороннього зв'язку, спрямованого на спільний пошук шляхів вирішення найактуальніших проблем; забезпечення довіри з боку громадян до влади.

\section{Висновки}

Конструктивна співпраця органів публічної влади з організаціями громадянського суспільства $є$ важливою умовою існування успішної демократичної держави, оскільки активні громадяни, реалізуючи свій потенціал, виступають партнерами держави у реалізації соціальних, економічних та правоохоронних функцій.

Основними проблемами у взаємодії органів публічного управління 3 організаціями громадянського суспільства можуть бути - намагання використовувати ОГС в латентному політичному процесі; створення штучних громадських рухів та ініціатив; недостатність фінансових інструментів та організаційних можливостей ОГС; ігнорування пропозицій та проектів ОГС з боку органів публічного управління.

Важливими умовами конструктивної взаємодії та співпраці органів влади з громадянами є:

- готовність даних суб'єктів до суспільно-державної взаємодії і зміцнення такої співпраці;

- субсидіарність інститутів громадянського суспільства, що є необхідним як для зацікавленості органів влади співпрацювати з громадянами, так і для чіткого й точного представлення своїх інтересів;

- наявність інституціалізованих правових та організаційних меж співпраці як для влади, так і для громадськості, а також рамок для здійснення партнерства (сталі форми їх взаємодії).

\section{Список використаної літератури}

1. Взаємодія держави та інституцій громадянського суспільства: роз'яснення Міністерства юстиції України від 03.02.2011 p. [Електронний ресурс]. - Режим доступу: http://zakon1.rada.gov.ua/laws/show/n001832311.

2. Взаємодія органів державної влади та громадянського суспільства / за наук. ред. д-ра соц. наук, проф. Ю. П. Сурміна, д-ра іст. наук, проф. А. М. Михненка; авт. кол. : Ю. П. Сурмін, А. М. Михненко, Т. П. Крушельницька та ін. - К. : НАДУ, 2011. - 388 с.

3. Громадянське суспільство України: сучасні практики та виклики розвитку : аналіт. доповідь / [Яблонський В. М., Андріученко Т. В., Бекешкіна I. Е. та ін.]; за заг. ред. О. А. Корнієвського, Ю. А. Тищенко, В. М. Яблонського. - К. : НІСД, 2018. - 128 с.

4. Колосовська I. І. Формування ефективної моделі партнерства інститутів публічної влади та громадянського суспільства / I. І. Колосовська // Збірник наукових праць. - 2015. - Вип. 45 «Ефективність державного управління» [Електронний ресурс]. - Режим доступу: http://nbuv.gov.ua/UJRN/efdu_2015_45_21.

5. Концепція взаємодії держави з громадянським суспільством (Проект) [Електронний ресурс]. Режим доступу: http://www.kmu.gov.ua/document/44502581/Proekt_Conc.doc

6. Національна стратегія сприяння розвитку громадянського суспільства в Україні на 2016-2020 роки : Указ Президента України від 26 лютого 2016 р. № 68/2016 [Електронний ресурс]. - Режим доступу: https://www.president.gov.ua/documents/682016-19805

7. Норт Д. Институты, институциональные изменения и функционирование экономики / Д. Норт. - М. : Фонд экон. кн. «Начала», 1997. - С. 17.

8. Питання сприяння розвитку громадянського суспільства в Україні : Указ Президента України від 25 січня 2012 p. № 3 [Електронний ресурс]. - Режим доступу: https://zakon.rada.gov.ua/laws/show/32/2012

9. Розвиток громадянського суспільства в Україні : аналіт. доп. / В. М. Яблонський, П. Ф. Вознюк, Д. М. Горєлов [та ін.]; за ред. О. А. Корнієвського, М. М. Розумного. - К. : НІСД, 2015. C. 51 .

10. Скакун О. Ф. Теорія права і держави / О. Ф. Скакун; пер. з рос. - Х.: Консум, 2001. - 656 с.

11. Співпраця органів влади та інститутів громадянського суспільства у сфері державної молодіжної політики в Україні : наук. розробка / авт. кол. : Є. І. Бородін, І. В. Хохрякова, Т. М. Тарасенко та ін. - К. : НАДУ, 2012. - 56 с.

12. Сурмін Ю. П. Концептуально-методологічні підходи осмислення сутності й тенденцій розвитку державної служби / Юрій Сурмін // Теорія та практика державного управління : зб. наук. пр. Х. : Вид-во ХарРІ НАДУ «Магістр», 2007. - Вип. 1 (16). - С. 354-363. 
13. Турій О. В. Окремі аспекти взаємодії організацій громадянського суспільства 3 органами державної влади як фактор розвитку громадянського суспільства / О. В. Турій // Державне управління: удосконалення та розвиток. - 2017. - № 8 .

14. Щодо активізації взаємодії організацій громадянського суспільства із органами державної влади. Аналітична записка [Електронний ресурс]. - Режим доступу: http://www.niss.gov.ua/articles/881.

\section{References}

1. Vzaiemodiia derzhavy ta instytutsii hromadianskoho suspilstva: roziasnennia Ministerstva yustytsii Ukrainy vid 03.02.2011 r. [Interaction between State and Civil Society Institutions: Declaration of the Ministry Of Justice of Ukraine dated 03.02.2011] Retrieved from http://zakon1.rada.gov.ua/laws/show/ n0018323-1.

2. Surmin Yu. P., \& Mykhnenko A. M., \& Krushelnytska T. P. (2011) Vzaiemodiia orhaniv derzhavnoi vlady ta hromadianskoho suspilstva : navch. Posib [Interaction between Public Authorities and Civil Society: Studying Manual]. - Kyiv: NADU [in Ukrainian].

3. Yablonskyi V. M., \& Andriuchenko T. V., \& Bekeshkina I. E. (2018) Hromadianske suspilstvo Ukrainy: suchasni praktyky ta vyklyky rozvytku: analit. Dopovid [Civil Society in Ukraine: Contemporary Practices And Challenges Of Development: Analytical Report]. - Kyiv: NISD [in Ukrainian].

4. Kolosovska I. I. (2015) Formuvannia efektyvnoi modeli partnerstva instytutiv publichnoi vlady ta hromadianskoho suspilstva [Formation of an Effective Model for Partnership between Public Authority Institutes and Civil Society] Retrieved from http://nbuv.gov.ua/UJRN/efdu_2015_45_21

5. Kontseptsiia vzaiemodii derzhavy $\mathrm{z}$ hromadianskym suspilstvom (Proekt) [The Concept of Interaction between State and Civil Society (Project)] Retrieved from http://www.kmu.gov.ua/document/44502581/Proekt_Conc.doc

6. Natsionalna stratehiia spryiannia rozvytku hromadianskoho suspilstva v Ukraini na 2016-2020 roky»/ Ukaz Prezydenta Ukrainy vid 26 liutoho 2016 r. № 68/2016 [The National Strategy for Promoting the Development of Civil Society in Ukraine for 2016-2020 / Decree of the President of Ukraine dated February 26, 2016 No. 68/2016] Retrieved from https://zakon2.rada.gov.ua/laws /show/68/2016

7. Nort D. (1997) Institutyi, institutsionalnyie izmeneniya i funktsionirovanie ekonomiki / D. Nort. [Institutes, Institutional Changes and Economy Functioning] - Moskva : Fond эkon. kn. «Nachala» [in Rossyia].

8. Pytannia spryiannia rozvytku hromadianskoho suspilstva v Ukraini: Ukaz Prezydenta Ukrainy vid 25 sichnia 2012 r. № 32/2012. [Issues of Promoting the Development of Civil Society in Ukraine: Decree of the President of Ukraine dated January 25, 2012 No. 32/2012] Retrieved from https://zakon.rada.gov.ua/ laws/show/32/2012

9. Yablonskyi V. M., \& Vozniuk P. F., \& Horielov D. M. (2015) Rozvytok hromadianskoho suspilstva v Ukraini : analit. dop. [Civil Society Development in Ukraine: Analytical Report] - Kyiv: NISD [in Ukrainian].

10. Skakun O. F. (2001) Teoriia prava i derzhavy: pidruchnyk / O. F. Skakun [Theory of Law and State: Textbook]. - Kharkiv: Konsum [in Ukrainian].

11. Borodin Ye. I., \& Khokhriakova I. V., \& Tarasenko T. M. (2012) Spivpratsia orhaniv vlady ta instytutiv hromadianskoho suspilstva u sferi derzhavnoi molodizhnoi polityky $v$ Ukraini : nauk. Rozrobka[Collaboration between Authorities and Civil Society Institutes in the Field of State Youth Policy in Ukraine: Scholar Research] - Kyiv: NADU [in Ukrainian].

12. Surmin Yu. P. (2007) Kontseptualno-metodolohichni pidkhody osmyslennia sutnosti y tendentsii rozvytku derzhavnoi sluzhby [Conceptual and Methodological Approaches to Understanding the Essence and Trends of Civil Service Development / Yurii Surmin // Theory and Practice of Public Management: Scholar Compilation] / Yurii Surmin // Teoriia ta praktyka derzhavnoho upravlinnia : zb. nauk. pr. - Kharkiv : Vyd-vo KharRI NADU «Mahistr» [in Ukrainian].

13. Turii O. V. Okremi aspekty vzaiemodii orhanizatsii hromadianskoho suspilstva z orhanamy derzhavnoi vlady yak faktor rozvytku hromadianskoho suspilstva [Some Aspects of the Interaction between Civil Society Organizations and Public Authorities as a Factor in the Civil Society Development] Retrieved from / https://www.dy.nayka.com.ua/?op=1\&z=1115

14. Shchodo aktyvizatsii vzaiemodii orhanizatsii hromadianskoho suspilstva iz orhanamy derzhavnoi vlady. Analitychna zapyska [On the Activation of Interaction between Civil Society Organizations and Public Authorities. Analytical Note] Retrieved from http://www.niss.gov.ua/articles/881. 